\title{
A new beaked whale record from the upper Miocene of Menorca, Balearic Islands, based on CT-scan analysis of limestone slabs
}

Giovanni Bianucci, Sergio Llàcer, Josep Quintana Cardona, Alberto Collareta, and Agustí Rodríguez Florit

Acta Palaeontologica Polonica 64 (2), 2019: 291-302 doi:https://doi.org/10.4202/app.00593.2019

The finding of significant vertebrate remains inside commercial stone blocks is relatively rare. Here we describe a fossil cetacean skull discovered inside two slabs cut from a limestone block of Tortonian (i.e., early late Miocene) age from Menorca (Balearic Islands, Spain); this find represents the third record of a fossil cetacean from this island, as well as the best preserved. Unlike similar cases in the past, the Menorca skull was not extracted mechanically from the stone matrix, being rather imaged by means of computed tomography. The resulting 3D reconstruction of the skull allows us to refer the studied skull to the extant odontocete family Ziphiidae (beaked whales) and sheds light on the morphology of very delicate structures (e.g., the thin pterygoid hamuli and the mesorostral cartilage) that would likely have been destroyed during traditional mechanical preparation. This non-invasive investigation permits detailed osteoanatomical comparisons between the Menorca specimen and other extinct ziphiids, leading to the referral of the former to the stem beaked whale Messapicetus cf. longirostris. We then review the geographic distribution of fossil remains of Messapicetus, which include other occurrences from Tortonian shelf deposits of southeastern Italy, southern Peru, and Maryland (eastern USA). Early branching beaked whales (including basal members of the so-called "Messapicetus clade") likely dispersed via the Central American Seaway, which allowed a direct communication between the Pacific and Atlantic oceans (including the Mediterranean cul-de-sac) throughout the Miocene.

Key words: Mammalia, Cetacea, Ziphiidae, Messapicetus, palaeobiogeography, Neogene, Mediterranean, Spain.

Giovanni Bianucci [giovanni.bianucci@unipi.it], Dipartimento di Scienze della Terra, Università di Pisa, via Santa Maria 53, 56126, Pisa, Italy. Sergio Llàcer [sergio.llacer@icp.cat ], Institut Català de Paleontologia Miquel Crusafont, Universitat Autònoma de Barcelona, Carrer de les Columnes s/n, 08193 Cerdanyola del Vallès, Barcelona, Spain. Josep Quintana Cardona [picoguevo@gmail.com], Institut Català de Paleontologia Miquel Crusafont, Universitat Autònoma de Barcelona, Carrer 
de les Columnes s/n, 08193 Cerdanyola del Vallès, Barcelona, Spain; Carrer Gustau Mas 79, 1er, 07760 Ciutadella de Menorca, Illes Balears, Spain.

Alberto Collareta [alberto.collareta@unipi.it], Dipartimento di Scienze della

Terra, Università di Pisa, via Santa Maria 53, 56126, Pisa, Italy. Agustí

Rodrígez Florit [a.rodriguez@geoservei.com], carrer Himàlaia 37, 07703 Maó, Illes Balears, Spain.

This is an open-access article distributed under the terms of the Creative Commons

Attribution License (for details please see creativecommons.org), which permits unrestricted use, distribution, and reproduction in any medium, provided the original author and source are credited.

For Full text $(1,295.6 \mathrm{kB})$ 